\title{
Sources of Extension Information for Growers in Miami-Dade County 1
}

\section{R. Muñoz-Carpena, J.H. Crane, and G. Israel $^{2}$}

\section{Introduction and background}

The Miami-Dade County agricultural industry employs over 14,000 people and has an economic impact exceeding $\$ 1.07$ billion on the state economy (Degner et al., 2002a). There is about 71,000 acres of commercial agriculture in Miami-Dade County with about $57 \%$ planted to vegetables, about $16 \%$ in nurseries, and $22 \%$ in fruit orchards; the rest $(\sim 5 \%)$ is used for livestock or is fallow. There are approximately 100 vegetable, 1,053 ornamental, and 823 fruit growers (Degner et al., 2002b; J. Crane, personal communication). In addition, Miami-Dade County's golf course industry generates sales in excess of $\$ 288$ million annually, covers an estimated 8,400 acres and employs an estimated 2,364 people (Haydu and Hodges, 2002).

Water use, management, and quality are major issues in Florida's Miami-Dade County where excessive rainfall (flooding) and extended dry spells (drought) are experienced periodically (Muñoz-Carpena et al., 2003abc; Muñoz-Carpena et al., 2004). Water use practices (e.g., irrigation and fertilizer management) may potentially affect the water quality of the Biscayne Aquifer, Biscayne Bay, and the Everglades. With this in mind a comprehensive water use and conservation practices survey was conducted during 2003. Results for the water use and conservation practices of the ornamental, vegetable, tropical fruit, and golf course industry of Miami-Dade County were previously reported (Muñoz-Carpena et al., 2003abc; Muñoz-Carpena et al., 2004).

Providing education programs to address and assist the agricultural and golf course industry is a primary mission of the Cooperative Extension Service. There are numerous public and private institutions and companies that provide education information to producers and managers.

Furthermore, there are many methods for notification of Extension programs and methods for providing educational materials. However, which sources of notification, information, and methods of providing information are important is unknown.

This fact sheet reports on the part of the survey that addressed growers sources of notification and information on water management and conservation in Miami-Dade County.

1. This document is ABE349, one of a series of the Agricultural and Biological Engineering Department, Florida Cooperative Extension Service, Institute of Food and Agricultural Sciences, University of Florida. Published February 2005. Please visit the EDIS Web site at http://edis.ifas.ufl.edu.

2. R. Muñoz-Carpena, Asst. Prof., Hydrologist, Agric. and Biol. Engineering Dept., Gainesville, FL; J.H. Crane, Prof. Tropcial Fruit Crop Specialist, Tropical Research and Education Center, Homestead, FL; G. Israel, Prof., Evaluation Specialist, Dept. of Ag. Ed. and Communication, Gainesville, FL; Cooperative Extension Service, IFAS, University of Florida, Gainesville. 


\section{Survey and analysis}

The survey involved a random sample of 898 agricultural and golf course water users in Miami-Dade County selected from mailing lists obtained from the Miami-Dade County/IFAS Cooperative Extension Service and other growers organizations in Miami-Dade County. The survey recipients were selected according to the size of their operation and was designed to obtain a maximum of 609 surveys overall. This represents close to $68 \%$ of the sampled population.

The survey instrument contained questions concerning the importance of issues facing growers and golf course managers, their participation in commodity-based organizations, preferred sources of educational information and presentation of information, preferred method of notification of educational programs, and computer use. The survey was tailored to each of the four main commodities in Miami-Dade County (vegetables, tropical fruits, ornamental plants, and golf courses).

The survey protocol adopted followed social sciences methodology to allow statistical analysis of results and the assessment of the influence of the economic, technical, and sociological factors on water conservation practices in the study area. Each potential respondent received a letter informing him or her of the purpose of the survey. Two weeks later the surveys were sent out and telephone follow up was done 4 and 8 weeks later. The survey data were analyzed using SAS software FREQ and MEANS statistical procedures (SAS, 1999).

\section{Survey results}

\section{Background}

The overall survey response rate was $27 \%$ (167 respondents). This represented $18 \%$ of the agricultural and golf course land area (Muñoz-Carpena et al., 2003abc; Muñoz-Carpena et al., 2004). Frequently mail-back survey response rates of 10 to $50 \%$ are common and some may be as low as $20 \%$, thus the response was considered satisfactory (Dolan et al., 2000; Nachimias and Nachimias, 1976; Neuman, 1997).

\section{Important issues for Miami-Dade County growers}

The percentage of growers rating various issues as important to very important varied by industry (Table 1). The most important issues for the ornamental growers were water shortages $(60 \%)$ and water quality (47\%). Vegetable producers overwhelmingly rated trade and competition (83\%) as their biggest issue followed by farm commodity prices $(50 \%)$. Fruit growers indicated farm commodity prices were most important (52\%) followed by water shortages (44\%). Flooding issues were rated as important to very important by $45 \%$, $33 \%, 41 \%$, and $63 \%$ of the ornamental, vegetable and fruit growers and golf course managers, respectively (Table 1). Plant pest issues were rated important to very important by $46 \%, 33 \%, 41 \%$, and $63 \%$ of the ornamental, vegetable and fruit growers, and golf course managers, respectively.

\section{Membership in grower organizations}

The number of commodity-based grower organizations also varied by commodity (Table 2). Eighty-seven percent of the ornamental growers belonged to the Florida Nursery and Grower Association and $67 \%$ to the Farm Bureau. All vegetable growers surveyed belonged to the Farm Bureau. Sixty-seven percent of the fruit growers surveyed belonged to the Tropical Fruit Growers of South Florida, followed by the Farm Bureau (44\%), the Avocado Committee (23\%), and Dade County AgriCouncil (12\%). The Farm Bureau is the largest farming organization in the State and is intimately involved in the numerous environmental, trade, and regulatory issues facing farmers. In addition they are involved in marketing and promotion of Florida's agriculture, agricultural policy, support of agricultural research and extension education, and representing the industry in the political arena.

\section{Sources of educational information}

The most important sources of educational information varied by commodity group (Table 3 ). The University of Florida's Cooperative Extension Service (UF Extension Service) was rated as a very 
important source of educational information by ornamental $(43 \%)$, vegetable (83\%), and fruit $(63 \%)$ growers. This was a greater percentage than any other public or private institution listed.

About 30 to $40 \%$ of the ornamental growers reported the Tropical Research and Education Center (TREC), company representatives, the South Florida Water Management District (SFWMD), other farmers, and family members/friends as very important sources of educational information (Table $3)$. Interestingly, $83 \%$ of the vegetable growers rated the UF Extension Service, private consultants, farm associations/groups, and farm media/trade magazines as very important sources of educational information (Table 3). TREC and company representatives were identified as very important by $67 \%$ of the vegetable growers. Fifty percent of the vegetable growers listed USDA-Agricultural Research Service (USDA-ARS), other farmers, and family members/friends as very important sources of educational information. TREC and company representatives were rated as very important by $54 \%$ and $39 \%$ of the fruit growers, respectively (Table 3 ). Thirty-five percent and 27\% of the fruit growers reported the SFWMD and other farmers as very important sources of educational information. More golf course managers identified family members/friends (50\%) as very important sources of information than farm associations/groups (38\%), UF Extension Service (38\%), and company representatives (25\%). Relatively few (13\%) identified the USDA, SFWMD, private consultants, irrigation companies, and farm media/trade magazines as very important sources of information.

\section{Program notification and type preferences}

Notification of future extension programs is critical to program success (Table 4). Ornamental and fruit growers preferred notice of extension programs by newsletters (69-71\%), mailed flyers (60-66\%), and through grower groups (35-40\%). Notification by word-of-mouth was about $34 \%$. In contrast, $50 \%$ of the vegetable growers preferred notification by facsimile (fax), newsletters, or word-of-mouth. Only about a third (33\%) of the vegetable growers preferred notification by mailed flyers, telephone, and grower groups. Newsletters and mailed flyers were preferred by $63 \%$ of the golf course managers. Notification by newspapers and email was rated low (11-24\%) and web sites was very low $(0-2 \%)$ for all commodity groups.

The preference in the method for receiving extension information varied by commodity group (Table 5). Ornamental growers preferred newsletters (67\%) and workshops (56\%) followed by publications (53\%), Web sites (47\%), and seminars $(41 \%)$. Vegetable growers preferred workshops, field days, and newsletters equally (67\%) followed by seminars, publications, and Web sites (50\%). Fruit growers preferred newsletters $(66 \%)$, workshops $(63 \%)$, field days $(52 \%)$, publications $(50 \%)$, seminars (45\%), and Web sites (45\%). Golf course managers preferred seminars $(63 \%)$ followed by workshops, field days, and newsletters (all at 50\%). Across industries, traditional methods like one-on-one meetings and telephone were rated low $(23 \%)$ to $(0 \%)$ very low (Table 5$)$. On the other hand, Web sites are emerging as a more important method for receiving extension information.

The mix of methods in which clientele prefer receiving extension information underlie the need to provide this information in several formats (e.g., newsletters, websites, workshops) to increase awareness and the likelihood the information will be useful and acted upon.

\section{Computer use}

Use of a computer and the Internet varied by group with most ornamental growers (89\%), all the vegetable growers $(100 \%)$, and most golf course managers $(75 \%)$ utilizing a computer and the Internet (80-100\%) (Table 6). In contrast, only a little more than half (58\%) of the fruit growers surveyed utilize a computer in their operation and only $49 \%$ indicated daily use. When asked if they would use an extension web site specific to Miami-Dade County only a third (33\%) of the vegetable growers and about half the ornamental and fruit growers and golf course managers responded positively.

\section{Discussion and conclusions}




\section{Ornamental growers.}

- Important sources of ornamental educational information included the Extension Service of the University of Florida, company representatives, and TREC (Table 3). Since nearly $40 \%$ of the ornamental growers find company representatives an important source of information, UF Extension Service offering programs to company representatives would probably increase the potential impact of current extension programs to the ornamental industry.

- Ornamental growers identified newsletters, workshops, publications, Web sites, and seminars as preferred methods of receiving extension information (Table 5). Increasing the use of the Internet (e-mail/Web) to notify ornamental growers of programs seems a logical path since most ornamental growers indicated they utilize a computer daily (Table 6).

Vegetable growers.

- Vegetable growers reported a number of important sources of information including UF Extension Service (83\%), farm associations/groups (83\%), private consultants (83\%), TREC $(67 \%)$ and company representatives (67\%) (Table 3$)$. This suggests an opportunity for UF Extension to develop programs for private consultants and company representatives which would increase the outreach and potential impact of programs. Vegetable growers preferred workshops, field days, and newsletters as methods to receive extension information although 50\% indicated they prefer receiving information through Web sites (Table 5).

- Computer use by vegetable growers is high (100\%) and many (80\%) utilize it daily (Table 6). This suggests an opportunity to increase extension programming and notification of programs via the internet. However none of the vegetable growers surveyed indicated they prefer notification of extension programs via Web sites (Table

5). There is a clear opportunity to offer practical training for growers and managers on the use of Internet resources to obtain Extension information.

Fruit growers.

- A majority of fruit growers indicated the UF Extension Service and TREC are very important sources of educational information (Table 3)

- Most preferred notification of extension programs via newsletters and mailed flyers (Table 4). However, due to budget constraints mailed flyers are not economically feasible and notification via newspapers and Web sites much more common. This may be a problem in the near term since only about $58 \%$ of the fruit growers indicated use of computers in their operation and only $1 \%$ indicated use of Web sites for notification of programs. This points to the need to promote computer use among fruit growers if educational information is to be provided in a timely and efficient manner.

- Newsletters, workshops, field days, and publications were all identified as preferred methods for receiving extension information (Table 5).

\section{Golf course managers.}

- Highly rated sources of educational information included family members (50\%) followed by UF Extension Service $(38 \%)$ and farm associations/groups (38\%) (Table 3). This reflects in part the fact that traditionally no specialized local (Miami-Dade County) Extension support has been available for this industry. However, there may be opportunity for Extension to offer educational programs to irrigation company employees and trade associations that serve the golf course industry thus increasing the Extension Service's educational impact. 
- Use of the computer by golf course managers is high $(75 \%)$ (Table 6) but use as a notification source was $0 \%$ (Table 4 ). It may be possible to increase the use of the Internet as a notification source through advertising and prompting at extension events as well as computer/Internet training.

\section{Conclusions}

Water use, management, and quality are major issues in Florida's Miami-Dade County. The fact that the Extension Service of the University of Florida was consistently highly rated as a source of educational information attests to the long tradition and effort by the University of Florida to provide science-based information to the horticultural industries of Florida. However, opportunities exist to train some of the other information providers for the industry (company representatives, private consultants) in a "train-the-trainers" effort. Utilization of computers is relatively high with most groups but its use to extend information and notification of programs needs improvement. There exist a clear opportunity to offer practical training for growers and managers on the use of computer/Internet resources (Web, e-mail) to obtain Extension information.

\section{Literature cited}

Degner, R.L., T.J. Stevens, and K.L. Morgan. 2002a. Miami-Dade County agricultural land retention study, summary and recommendations, Vol. 1. Fla. Agri. Market Res. Center, IFAS, University of Florida, Gainesville, Fla. p. 89.

Degner, R.L., T.J. Stevens, and K.L. Morgan. 2002b. Miami-Dade County agricultural land retention study, economic issues, Vol. 3. Fla. Agri. Market Res. Center, IFAS, University of Florida, Gainesville, Fla. p. 201.

Dolan, A.H., R. Kreutzwiser, and R. de Loë. 2000. Rural water use and conservation in southwestern Ontario. J. Soil and Water Conservation 55:161-171.

Haydu, J.J. and A.W. Hodges. 2002. Economic impacts of the Florida golf course industry, Econ.
Information Report IER 01-4. Food and Resource Economics Dept., FLa. Coop. Ext. Service, Gainesville, Fla. p.34.

Muñoz-Carpena, R., J.H. Crane, G.D. Israel, and J. Garofalo. 2003a. Ornamental growers' water use and conservation practices in Miami-Dade County, AE260. Fla. Ext. Service, IFAS, Univ. of Fla., Gainesville, Fla. p. 4

(http://edis.ifas.ufl.edu/pdffiles/AE/AE26000.pdf).

Muñoz-Carpena, R., J.H. Crane, G.D. Israel, and T. Olczyk. 2003b. Vegetable growers' water use and conservation practices in Miami-Dade County, AE258. Fla. Ext. Service, IFAS, Univ. of Fla., Gainesville, Fla. p. 5

(http://edis.ifas.ufl.edu/pdffiles/AE/AE25800.pdf).

Muñoz -Carpena, R., J.H. Crane, G.D. Israel, and C.F. Balerdi. 2003c. Tropical fruit growers' water use and conservation practices in Miami-Dade County, AE257. Fla. Ext. Service, IFAS, Univ. of Fla., Gainesville, Fla. p. 5 (http://edis.ifas.ufl.edu/pdffiles/AE/AE25700.pdf).

R. Muñoz-Carpena, J.H. Crane, G.D. Israel, and C. Yurgalevitch. 2004. Golf courses water use and conservation practices in Miami-Dade County. Fla. Coop. Ext. Serv., IFAS, Univ. of Fla., Gainesville, Fla. P. 1-4.

(http://edis.ifas.ufl.edu/pdffiles/AE/AE25900.pdf).

Nachmias D. and C. Nachmias. 1976. Research Methods in the Social Sciences. New York: St. Martins Press.

Neuman, L.W. 1997. Social Research Methods: Qualitative and Quantitative Approaches. 3 ${ }^{\text {rd }} \mathrm{ed} /$ Boston: Allyn and Bacon.

SAS Institute Inc. 1999. SAS 8.01 [Computer software]. Cary, NC. 
Table 1. The percentage of fruit, ornamental, and vegetable growers, and golf course managers rating specific issues as important to very important.

\begin{tabular}{||l|c|c|c|c||}
\hline & \multicolumn{4}{|c||}{ Percentage } \\
\hline Issue & Ornamental & Vegetable & Fruit & $\begin{array}{c}\text { Golf } \\
\text { course }\end{array}$ \\
\hline Water shortages & 60 & 17 & 44 & 88 \\
\hline Flooding & 45 & 33 & 41 & 63 \\
\hline Water quality & 47 & 31 & 40 & 75 \\
\hline Plant pests & 46 & 33 & 41 & 63 \\
\hline $\begin{array}{l}\text { Trade/ } \\
\text { competition }\end{array}$ & 30 & 83 & 42 & 13 \\
\hline $\begin{array}{l}\text { Farm commodity } \\
\text { prices }\end{array}$ & 18 & 50 & 52 & $\mathrm{NA}^{\mathrm{z}}$ \\
\hline $\mathrm{z}, \mathrm{NA}$, not asked. & & & & \\
\hline \hline
\end{tabular}

Table 2. Percentage of ornamental, vegetable, and fruit growers that belong to various grower organizations.

\begin{tabular}{||l|l|c||}
\hline \hline $\begin{array}{l}\text { Commodity } \\
\text { group }\end{array}$ & Organization & $\begin{array}{c}\text { Percent } \\
\text { members }\end{array}$ \\
\hline Ornamental & Farm Bureau & 67 \\
\hline Vegetable & $\begin{array}{l}\text { Florida Nursery and } \\
\text { Grower } \\
\text { Association }\end{array}$ & 87 \\
\hline Fruit & Farm Bureau & 100 \\
\hline & $\begin{array}{l}\text { Tropical Fruit } \\
\text { Growers of South } \\
\text { Florida }\end{array}$ & 67 \\
\hline & Farm Bureau & 44 \\
\hline & $\begin{array}{l}\text { Avocado } \\
\text { Committee }\end{array}$ & 23 \\
\hline & $\begin{array}{l}\text { Dade County } \\
\text { AgriCouncil }\end{array}$ & 12 \\
\hline & $\begin{array}{l}\text { Florida Mango } \\
\text { Forum }\end{array}$ & 10 \\
\hline & \multicolumn{2}{|l|}{} \\
\hline
\end{tabular}

Table 3. Selected sources of educational information and the percentage of fruit, vegetable, and ornamental growers, and golf course managers rating the source as very important.

\begin{tabular}{||l|l|l|l|l||}
\hline \hline & \multicolumn{3}{|c||}{ Percentage } \\
\hline Source & Ornamental & Vegetable & Fruit & Golf course \\
\hline \hline
\end{tabular}


Table 3. Selected sources of educational information and the percentage of fruit, vegetable, and ornamental growers, and golf course managers rating the source as very important.

\begin{tabular}{|c|c|c|c|c|}
\hline $\begin{array}{l}\text { UF Extension } \\
\text { Service }^{z}\end{array}$ & 43 & 83 & 63 & 38 \\
\hline TREC $^{z}$ & 34 & 67 & 54 & 13 \\
\hline USDA-NRCS ${ }^{2}$ & 19 & 33 & 19 & 13 \\
\hline USDA-ARS ${ }^{z}$ & 32 & 50 & 25 & 13 \\
\hline SFWMD & 22 & 17 & 35 & 0 \\
\hline $\begin{array}{l}\text { Company } \\
\text { representatives }\end{array}$ & 39 & 67 & 39 & 25 \\
\hline $\begin{array}{l}\text { Private } \\
\text { consultants }\end{array}$ & 31 & 83 & 21 & 13 \\
\hline $\begin{array}{l}\text { Farm } \\
\text { associations/ } \\
\text { arouns }\end{array}$ & 26 & 83 & 16 & 38 \\
\hline $\begin{array}{l}\text { Other farmers/ } \\
\text { managers }\end{array}$ & 31 & 50 & 27 & 13 \\
\hline $\begin{array}{l}\text { Family } \\
\text { members or } \\
\text { friends }\end{array}$ & 31 & 50 & 18 & 50 \\
\hline $\begin{array}{l}\text { Irrigation } \\
\text { company reps } \\
\end{array}$ & 23 & 33 & 8 & 13 \\
\hline $\begin{array}{l}\text { Farm } \\
\text { media/trade } \\
\text { magazines }\end{array}$ & 20 & 83 & 18 & 13 \\
\hline \multicolumn{5}{|c|}{$\begin{array}{l}\text { z, UF, University of Florida; TREC, Tropical Research and Education Cent } \\
\text { USDA-NRCS, United States Department of Agriculture-Natural Resource } \\
\text { Conservation Service; USDA-ARS, USDA-Agricultural Research Service; } \\
\text { SFWMD, South Florida Water Management District. }\end{array}$} \\
\hline
\end{tabular}

Table 4. The percentage of fruit, vegetable, and ornamental growers, and golf course managers notified of extension programs by various media.

\begin{tabular}{||l|c|c|c|c||}
\hline \hline & \multicolumn{4}{|c||}{ Percentage } \\
\hline $\begin{array}{l}\text { Source of } \\
\text { notice }\end{array}$ & Ornamental & Vegetable & Fruit & $\begin{array}{c}\text { Golf } \\
\text { course }\end{array}$ \\
\hline Email & 13 & 17 & 24 & 13 \\
\hline Newsletters & 69 & 50 & 71 & 63 \\
\hline Mailed flyers & 66 & 33 & 60 & 63 \\
\hline Telephone & 8 & 33 & 8 & 25 \\
\hline Web sites & 2 & 0 & 1 & 0 \\
\hline Facsimile & 28 & 50 & 11 & 0 \\
\hline Word of mouth & 34 & 50 & 34 & 25 \\
\hline Newspapers & 11 & 17 & 24 & 13 \\
\hline Posted notices & 10 & 17 & 8 & 13 \\
\hline Grower groups & 40 & 33 & 35 & 13 \\
\hline \hline
\end{tabular}


Table 5. Fruit, vegetable, and ornamental growers, and golf course managers preferred method of receiving extension information.

\begin{tabular}{||l|c|c|c|c||}
\hline \hline & \multicolumn{4}{|c||}{ Percentage } \\
\hline Method & Ornamental & Vegetable & Fruit & $\begin{array}{c}\text { Golf } \\
\text { course }\end{array}$ \\
\hline Workshops & 56 & 67 & 63 & 50 \\
\hline Seminars & 41 & 50 & 45 & 63 \\
\hline Field days & 38 & 67 & 52 & 50 \\
\hline Publications & 53 & 50 & 50 & 38 \\
\hline Newsletters & 67 & 67 & 66 & 50 \\
\hline Newspapers & 19 & 0 & 21 & 23 \\
\hline Web sites & 47 & 50 & 45 & 38 \\
\hline $\begin{array}{l}\text { One-on- } \\
\text { one }\end{array}$ & 13 & 0 & 23 & 0 \\
\hline Telephone & 6 & 17 & 11 & 13 \\
\hline \hline
\end{tabular}

Table 6. The percentage of fruit, vegetable, and ornamental growers, and golf course managers utilizing a computer and the internet.

\begin{tabular}{||l|c|c|c|c||}
\hline \hline & \multicolumn{4}{|c||}{ Percentage } \\
\hline Survey qustion & Ornamental & Vegetable & Fruit & Golf course \\
\hline $\begin{array}{l}\text { Utilize a computer } \\
\text { in their operation }\end{array}$ & 89 & 100 & 58 & 75 \\
\hline $\begin{array}{l}\text { Frequency of } \\
\text { computer use }\end{array}$ & 83 & 80 & 49 & 100 \\
\hline - Daily & 12 & 20 & 35 & 0 \\
\hline - Weekly & 5 & 0 & 16 & 0 \\
\hline $\begin{array}{l}\text { Monthly or } \\
\text { less }\end{array}$ & 48 & 33 & 54 & 50 \\
\hline $\begin{array}{l}\text { Would use an } \\
\text { extension Web site } \\
\text { specific for } \\
\text { Miami-Dade } \\
\text { County }\end{array}$ & & & & \\
\hline \hline
\end{tabular}

